\title{
The effect of color type on early wound healing in farmed mink (Neovison vison)
}

\author{
A. Jespersen ${ }^{1,2,5^{*}}$, H. E. Jensen ${ }^{2}$, J. F. Agger ${ }^{3}$, P. M. H. Heegaard', P. Damborg ${ }^{2}$, B. Aalbæk ${ }^{2}$ and A. S. Hammer ${ }^{2}$
}

\begin{abstract}
Background: Individual differences of mink, including color type, are speculated to affect the course of wound healing, thereby impacting wound assessment and management on the farms, as well as the assessment of wounds in forensic cases. In this study, we examined the effect of color type on early wound healing in farmed mink. Full thickness excisional wounds $(2 \times 2 \mathrm{~cm})$ were made on the back in 18 mink of the color types Brown, Silverblue and Blue Iris. Gross and microscopic pathology of the wounds was evaluated 2 days post-wounding together with degree of wound size reduction, presence of bacteria and blood analyses.

Results: Pathological examination on day 2 showed the greatest mean wound size reduction in Brown mink (11.0\%) followed by Blue Iris (7.9\%) and Silverblue (1.6\%). Bacteria were cultured from all wounds, and predominantly Staphylococcus species were recovered in mixed or pure culture. Histopathology from day 2 wounds showed a scab overlying necrotic wound edges, which were separated from underlying vital tissue by a demarcation zone rich in polymorphonuclear leukocytes. Fibroblasts and plump endothelial cells were more numerous in the deeper tissues. Complete blood count parameters were within normal ranges in most cases, however, the mink showed mildly to markedly decreased hematocrit and six mink of the color types Silverblue and Blue Iris showed moderately elevated numbers of circulating segmented neutrophils on day 2. There was a marked increase in concentration of serum amyloid A from day 0 to day 2 in all color types.

Conclusions: We have described differences in early wound healing between mink of the color types Brown, Silverblue and Blue Iris by use of an experimental wound model in farmed mink. The most pronounced difference pertained to the degree of wound size reduction which was greatest in Brown mink, followed by Blue Iris and Silverblue, respectively.
\end{abstract}

Keywords: Mink, Neovison Vison, Serum amyloid a, Wound healing, Wound model

\section{Background}

Wounds in farmed mink are important due to their influence on animal welfare [1]. It is estimated that around $10 \%$ of mortality during growth season is caused by wounds in well-managed farms [2, 3]. The appearance, size, location and causal mechanisms of wounds may vary significantly in mink according to time of year and age [4]. Furthermore, some wound types may occur more frequently in mink of certain color types [4].

\footnotetext{
* Correspondence: ajes@sund.ku.dk

'Kopenhagen Fur, Langagervej 60, DK-2600 Glostrup, Denmark

2Department of Veterinary Disease Biology, Faculty of Health and Medical Sciences, University of Copenhagen, Ridebanevej 3, DK-1870 Frederiksberg C, Denmark

Full list of author information is available at the end of the article
}

Knowledge on wound healing in mink is sparse, yet important for the optimization of wound assessment and management. Only one study has previously dealt with the healing of mink wounds. In that study, wound healing on day 12 post-wounding and later was described [5]. Forensic cases present a challenge, as the age assessment of wounds is based on knowledge of healing in other species, and not on healing in the mink per se. Due to the lack of reparative tissue, the early stages of healing are specifically challenging to assess, but offer the unique and timely presence of specific inflammatory cells, which can be studied for more accurate determination of wound age $[6,7]$. Wound healing has been studied extensively in a variety of species, especially in laboratory animals used for models of human disease [8-10]. Considering the aim, different wound models 
have been developed to mimic specific wound types and conditions $[10,11]$. Wound healing in other animal species has largely been studied to build knowledge for use in veterinary medicine regarding clinical aspects like wound assessment and therapy. From the carnivore order, wound healing in the dog and cat has been most extensively studied [12-14].

Intrinsic and extrinsic factors may influence the exact pathophysiology and course of wound healing [15]. Some fur colors of different animal species are linked to specific genetic conditions $[16,17]$. In mink, the Aleutian coat color allele, resulting in a bluish grey fur color, is linked to the autosomal recessive Chédiak-Higashi syndrome, also known from humans and other species [18]. Although the syndrome seems to be more subtle in mink than in other species, and does not cause any clinical abnormalities, this color type is anecdotally more susceptible to disease than the brown wild type mink. As in other species, the condition in mink is characterized by neutrophilic changes characterized by giant granules, which have been found to be large lysosomal vesicles showing impaired degranulation [18-22]. This defect is known to affect the ability to fight bacterial infections $[18,20,21]$. We speculate that the syndrome may also affect the course of wound healing, especially in the early phases of wound healing, where inflammation and the presence of neutrophils is most pronounced [23]. Hypothetically, the neutrophilic changes would lead to a defect in the innate immune system causing inferior removal of invading microorganisms by the neutrophils
[18, 20-22]. This would contribute to an increased microbial load and thereby increased susceptibility to infection. The increased microbial load would likely contribute to an altered inflammatory response due to increased recruitment of inflammatory cells to the site of injury [24-26], or there may be decreased recruitment due to defective chemotaxis [27]. Furthermore, wound closure, mediated by the replacement of lost tissue as well as wound contraction, may hypothetically be halted, or at least altered, since these mechanisms are known to be affected by the bacterial concentration and the composition of the wound microbiome [24-26]. Considering this, the Chédiak-Higashi syndrome may be of importance to the fur industry, as there may be practical implications for managing wounds in this color type.

Thus, the aim of the present study was to examine possible variations in early wound healing processes, including pathology, hematology, acute phase reaction and bacteriology, in a wound model in mink of different color types, i.e. the wild type (Brown), a blue type (Silverblue) and a pure Aleutian type (Blue Iris).

\section{Methods}

\section{Animals}

In total, 18 healthy commercially bred American mink of the color types Brown $(n=6)$, Silverblue $(n=6)$ and Blue Iris $(n=6)$ (Table 1$)$ were purchased from a Danish farm and transferred to the research farm at the University of Copenhagen. The mink were kept singly in standard cages according to Danish legislation and were

Table 1 Animal data

\begin{tabular}{|c|c|c|c|c|c|}
\hline Mink number & Color type & Sex & Age & Body weight pre surgery & Body weight 48 h post surgery \\
\hline 1 & Brown & $\hat{0}$ & 4 months & $1861 \mathrm{~g}$ & $1740 \mathrm{~g}$ \\
\hline 2 & Brown & 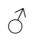 & 4 months & $2806 \mathrm{~g}$ & $2700 \mathrm{~g}$ \\
\hline 3 & Brown & 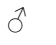 & 4 months & $2032 \mathrm{~g}$ & $2000 \mathrm{~g}$ \\
\hline 4 & Brown & $\hat{0}$ & 4 months & $2403 \mathrm{~g}$ & $2380 \mathrm{~g}$ \\
\hline 5 & Brown & $\hat{0}$ & 4 months & $2656 \mathrm{~g}$ & $2580 \mathrm{~g}$ \\
\hline 6 & Brown & $\hat{o}$ & 4 months & $2483 \mathrm{~g}$ & $2480 \mathrm{~g}$ \\
\hline 7 & Silverblue & $\hat{0}$ & 4 months & $2761 \mathrm{~g}$ & $2660 \mathrm{~g}$ \\
\hline 8 & Silverblue & $\hat{0}$ & 4 months & $1752 \mathrm{~g}$ & $1640 \mathrm{~g}$ \\
\hline 9 & Silverblue & $\hat{0}$ & 4 months & $2531 \mathrm{~g}$ & $2440 \mathrm{~g}$ \\
\hline 10 & Silverblue & $\hat{o}$ & 4 months & $2636 \mathrm{~g}$ & $2500 \mathrm{~g}$ \\
\hline 11 & Silverblue & $\hat{0}$ & 4 months & $1748 \mathrm{~g}$ & $1640 \mathrm{~g}$ \\
\hline 12 & Silverblue & $\hat{0}$ & 4 months & $2679 \mathrm{~g}$ & $2600 \mathrm{~g}$ \\
\hline 13 & Blue Iris & $\hat{0}$ & 4 months & $2490 \mathrm{~g}$ & $2400 \mathrm{~g}$ \\
\hline 14 & Blue Iris & $\hat{0}$ & 4 months & $2529 \mathrm{~g}$ & $2540 \mathrm{~g}$ \\
\hline 15 & Blue Iris & 0 & 4 months & $2285 \mathrm{~g}$ & $2220 \mathrm{~g}$ \\
\hline 16 & Blue Iris & 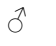 & 4 months & $2394 \mathrm{~g}$ & $2140 \mathrm{~g}$ \\
\hline 17 & Blue Iris & 0 & 4 months & $2284 \mathrm{~g}$ & $2200 \mathrm{~g}$ \\
\hline 18 & Blue Iris & 0 & 4 months & $2204 \mathrm{~g}$ & $2100 \mathrm{~g}$ \\
\hline
\end{tabular}


allowed 3 days for acclimatization upon arrival to the facility. The daily care and supervision was carried out by trained animal caretakers as well as the research participants. The feed consisted of a mink diet from a commercial feed kitchen. The mink were fed ad libitum and had free access to tap water.

\section{Experimental procedure}

The mink were weighed (Table 1) and anaesthetized with a combination of ketamine $(5 \mathrm{mg} / \mathrm{kg})$ and medetomidine $(0.08 \mathrm{mg} / \mathrm{kg})$ intramuscularly after premedication with an intramuscular injection of buprenorphine (0.02 $\mathrm{mg} / \mathrm{kg})$. Body temperature was monitored during anesthesia. The mink were surgically prepared by removing the fur at the surgical site with electrical clippers as well as by washing with chlorhexidine-cetrimide followed by $70 \%$ ethanol. A skin area of $2 \times 2 \mathrm{~cm}$ in the dorsal midline of the thorax, at the caudal margin of the shoulder blades, was outlined with a marker pen using a plastic template which was disinfected with $70 \%$ ethanol. A new template was used for each mink. One square, full thickness excisional wound (including the panniculus carnosus) was then generated in each mink by use of scalpel and scissors. The excised skin was harvested for histological analysis. Photos of the surgical areas were taken before and after surgery, and the length and width of the wounds was measured with a caliper postsurgery. Anesthesia was reversed by intramuscular injection of atipamezole $(0.4 \mathrm{mg} / \mathrm{kg})$ and the mink were returned to their cages, receiving buprenorphine $(0.02 \mathrm{mg} / \mathrm{kg})$ intramuscularly every $6-8 \mathrm{~h}$ throughout the first $24 \mathrm{~h}$ after surgery for pain relief. The wounds were left open for $48 \mathrm{~h}$ with regular supervision of the mink and their feed intake.

Blood for analysis of the acute phase protein serum amyloid A (SAA) and hematology was sampled prior to surgery and at euthanasia $48 \mathrm{~h}$ post-surgery. The blood was sampled from the cephalic vein after immobilization of the mink in a trap. Before euthanasia, blood was sampled directly from the heart. Serum was retrieved after coagulation for $30 \mathrm{~min}$ at room temperature and spinning of the tubes. The samples were stored at $-80{ }^{\circ} \mathrm{C}$ for up to 6 weeks until analyzed for SAA. A commercially available multispecies sandwich ELISA was applied for determination of mink SAA. This assay is based on anti-human monoclonal antibodies in a sandwich setup [28]. Samples were analyzed according to the manufacturer's instructions for canine SAA with the lowest sample dilution factor being 500. The detection limit of the assay was $5 \mathrm{mg} / \mathrm{L}$ (canine SAA equivalents). EDTA tubes were kept at $5{ }^{\circ} \mathrm{C}$ for a maximum of $4 \mathrm{~h}$ until processing for complete blood counts. Values were compared to reference ranges in mink and ferrets $[29,30]$.

All mink were euthanized $48 \mathrm{~h}$ after surgery by intracardiac injection of pentobarbital with lidocaine following anaesthetization as described above. After euthanasia, the mink were weighed (Table 1), and wounds were photographed, measured and assessed visually for appearance of scabs, undermining of skin, granulation tissue, epithelialization, edema and exudate. Swabs for bacteriological examination were taken from all wounds. The swabs were cultured on $5 \%$ calf blood agar, and incubated aerobically at $37{ }^{\circ} \mathrm{C}$ for 2 days. Subcultures of each morphologically distinct colony type were examined by matrix-assisted laser desorption/ionization time of flight (MALDI-TOF) mass spectrometry using Escherichia coli ATCC 8739 as reference strain and Saramis ${ }^{\text {TM }} 3.5$ for spectra interpretation. The wounds were then removed in toto and the mink necropsied [31]. Tissue samples for histopathological analysis consisted of samples from the spleen, right liver lobe, regional lymph nodes (mandibular, superficial cervical and subscapular/axillary), and adrenal glands. Control tissue consisted of skin samples from the left thigh as well as the mesenteric lymph node. All tissue samples were processed routinely after preservation in $10 \%$ neutral buffered formalin for 2 days, and stained with hematoxylin and eosin (HE). Masson trichrome stain was applied to wound tissue for visualization of collagen [32]. Histological examination with semi-quantitative assessment of epithelialization, polymorphonuclear leukocytes (PMNL), monocytes/tissue macrophages (MM), fibroblasts and endothelial cell activity was performed on all wound specimens using the scoring system given in Table 2. The area of the wounds was calculated from the measurements on day 0 and 2 , respectively. The percentile

Table 2 Histological parameters and semi-quantitative scoring system for day 2 wounds

\begin{tabular}{|c|c|c|c|c|c|}
\hline Scale & Epithelialization & $P M N L^{a}$ & $M M^{b}$ & Fibroblasts & Endothelial cell activity \\
\hline 0 & $\begin{array}{l}\text { No proliferation at } \\
\text { wound edge }\end{array}$ & No or very few cells present & $\begin{array}{l}\text { No or very few } \\
\text { cells present }\end{array}$ & $\begin{array}{l}\text { No or very few plump } \\
\text { fibroblasts present }\end{array}$ & $\begin{array}{l}\text { No vessels with plump } \\
\text { endothelial cells }\end{array}$ \\
\hline 1 & $\begin{array}{l}\text { Hyperplasia/hypertrophy } \\
\text { at wound edge }\end{array}$ & $\begin{array}{l}\text { Few cells or focal pattern, } \leq 40 \% \\
\text { of total cellularity }\end{array}$ & $\begin{array}{l}\leq 20 \% \text { of total } \\
\text { cellularity }\end{array}$ & $\begin{array}{l}\geq 50 \% \text { spindle cells, } \\
\leq 50 \% \text { plump fibroblasts }\end{array}$ & $\begin{array}{l}\leq 50 \% \text { vessels with plump } \\
\text { endothelial cells }\end{array}$ \\
\hline 2 & $\begin{array}{l}\text { Migration of cells over } \\
\text { wound bed }\end{array}$ & $\begin{array}{l}\text { Numerous cells present in all } \\
\text { layers, } \geq 40 \% \text { of total cellularity }\end{array}$ & $\begin{array}{l}\geq 20 \% \text { of total } \\
\text { cellularity }\end{array}$ & $\begin{array}{l}\geq 50 \% \text { plump fibroblasts, } \\
\leq 50 \% \text { spindle cells }\end{array}$ & $\begin{array}{l}\geq 50 \% \text { vessels with plump } \\
\text { endothelial cells }\end{array}$ \\
\hline
\end{tabular}

${ }^{a}$ polymorphonuclear leukocytes; ${ }^{b}$ monocytes/tissue macrophages 
reduction of the wound size from day 0 to day 2 was calculated as a measure of wound contraction:

$$
\text { Wound size reduction }=100-\left(\frac{\text { wound area day } 2}{\text { wound area day 0 }} \times 100\right) \text {. }
$$

For SAA, paired-samples t-test and ANOVA (test variable: pre and post-wounding concentration difference) was used to test for pre and post-wounding differences as well as differences between color types, respectively. ANOVA was used to test for differences between groups
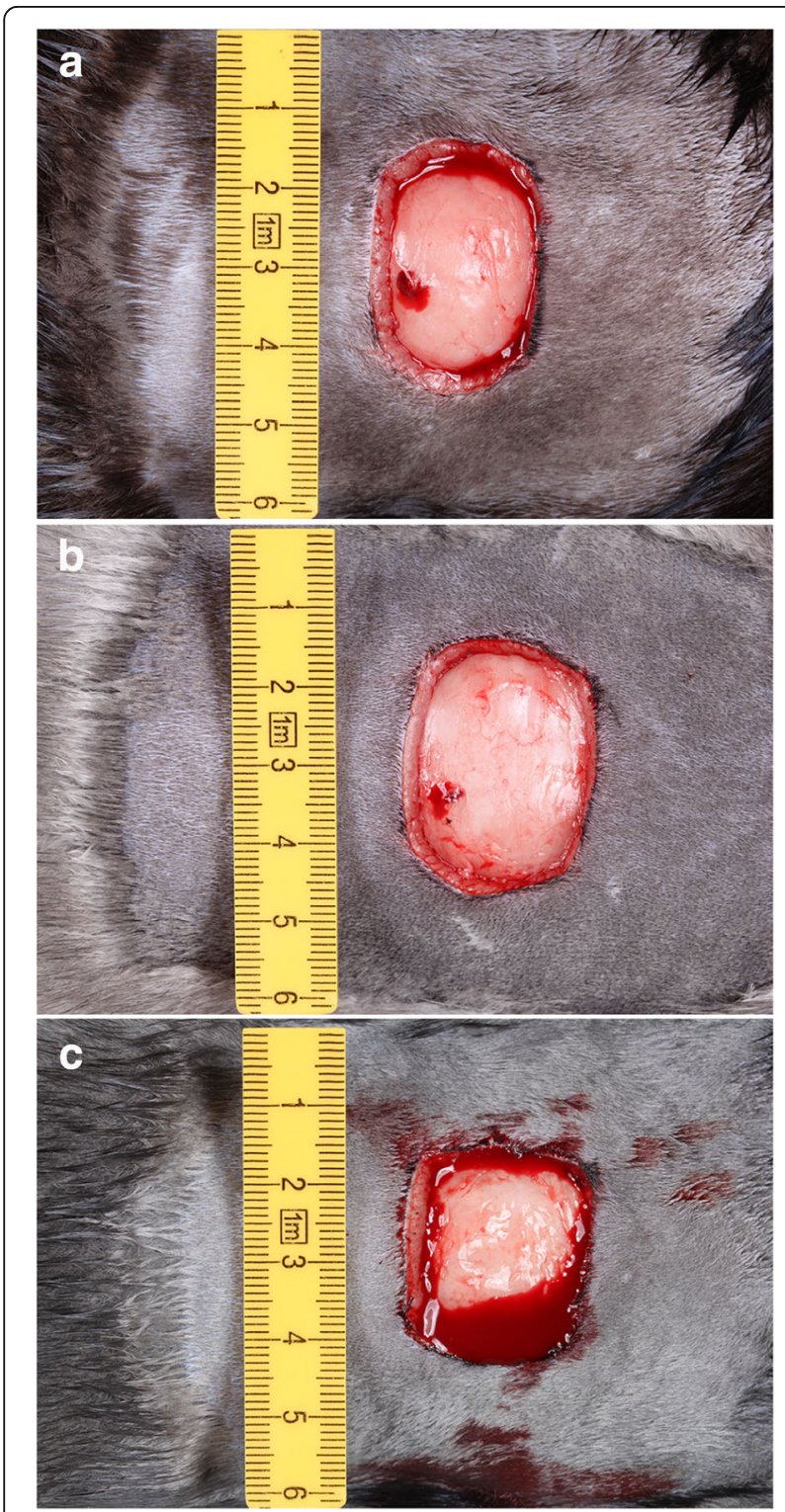

Fig. 1 Wounds day 0, immediately post-surgery. The wounds have expanded, primarily in a latero-lateral direction, from the $4 \mathrm{~cm}^{2}$ template. a: Brown, b: Silverblue, c: Blue Iris. Note the more profound bleeding in the Blue Iris color type with respect to wound contraction. $P<0.05$ was considered statistically significant.

\section{Results}

Clinical findings and gross pathology

Hemostasis occurred a few minutes after wound infliction in all mink except those of the color type Blue Iris, which displayed prolonged bleeding for up to 1 hour. While cutting the skin, the wound size expanded from the original $4 \mathrm{~cm}^{2}$ template in the latero-lateral direction (Fig. 1a-c).

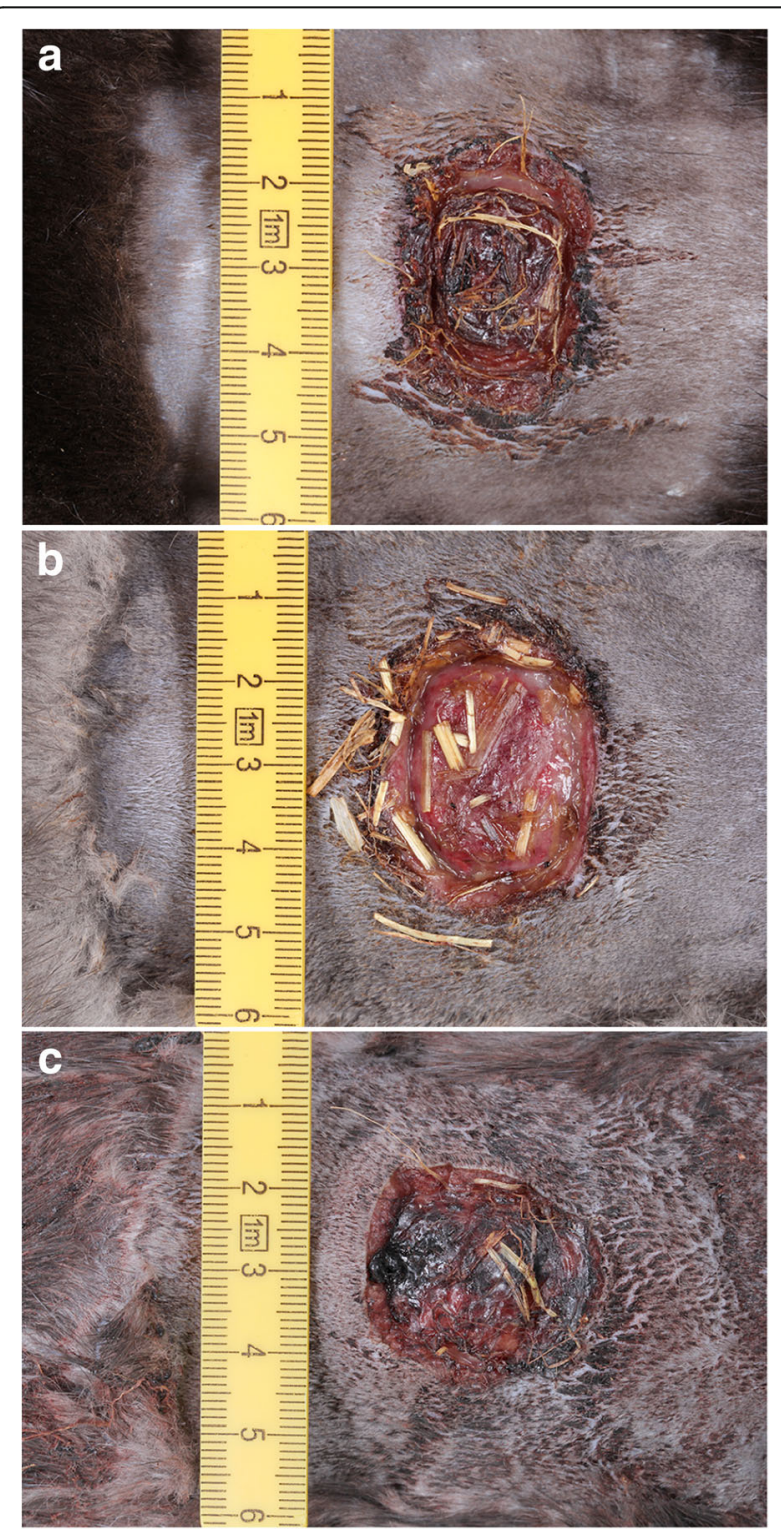

Fig. 2 Wounds day 2, at necropsy. The wounds show varying degree of scab formation, contamination with foreign (bedding) material as well as exudation. a: Brown, b: Silverblue, c: Blue Iris. Exudate was primarily seen along the wound margins, if present (Fig. 2a) 
At necropsy on day 2 post-surgery, a scab of varying thickness had formed in all cases, which partly or fully covered the wounds (Fig. 2a-c). The scab was most pronounced in mink of the color type Blue iris and Brown (Fig. 2). The cut edges were slightly thickened due to edema, and a cloudy to hemorrhagic serous exudate was seen along the wound margins in all but one mink of the Brown color type. Three mink of the color type Blue Iris showed a more purulent type of exudate, whereas the same was true in two Brown and two Silverblue mink. Furthermore, all mink showed mild to moderate splenomegaly and lymphadenopathy of regional lymph nodes.

The mink on average lost $87.4 \mathrm{~g}$ of body weight (average $3.8 \%$ ) from day 0 to day 2 . For the color types Brown, Silverblue and Blue Iris the weight loss averaged $2.7 \%$ (range -121 to $-3 \mathrm{~g}$ ), $4.7 \%$ (range -136 to $-79 \mathrm{~g}$ ) and $4.2 \%$ (range -254 to $+11 \mathrm{~g}$ ), respectively.

\section{Wound size}

The differences in wound size reduction for the three color types are shown in Fig. 3. Brown mink had the greatest mean reduction (11.0\%) followed by Blue Iris $(7.9 \%)$ and Silverblue (1.6\%). Four mink of the Silverblue color type showed a negative reduction, i.e. an increase in wound size from day 0 to day 2, ranging from -1.1 to -9.8. For Brown and Blue Iris mink, two of each color type showed a negative reduction of -1.1 and -7.3 (Brown) and -4.8 and -8.0 (Blue Iris), respectively. The difference in wound size reduction was found not significant with ANOVA $(\mathrm{F}=0.926 ; \mathrm{df}=2 ; P=0.418)$.

\section{Histopathology}

Day 0 skin samples showed no differences between color types and were characterized by intact skin with composite hair follicles and sebaceous glands overlying the panniculus carnosus muscle and a fatty subcutis.
On day 2 , the wounds were partially or completely covered by scab material consisting of intermixed necrotic tissue, debris, fibrin and erythrocytes (Fig. 4a). Bacterial colonies of cocci were found in all wound specimens as small clusters in the scab or more widespread on the wound surface. In all wounds there were also mild to moderate degrees of bleeding and deposits of fibrin as well as edema and distended lymph vessels. A demarcation zone of PMNL was separating the scab and necrotic tissue at the cut edges and in the wound bed from vital tissue (Fig. 4a). MM were present in smaller numbers. The ratio of PMNL to MM shifted towards the deeper tissues, with increasing numbers of MM relative to PMNL. Microabscesses or cellulitis were seen in the connective tissue beneath the demarcation line in 4 specimens (Fig. 4b). Plump fibroblasts were most predominant in the deeper subcutaneous tissues, however, collagen deposition was not observed in Masson trichrome stained sections. Sprouting of blood vessels was not evident, but some endothelial cells of existing blood vessels showed plumping with gap formation between adjacent cells (score 1-2, Table 2) as a sign of activity (Fig. 4c).

The semi-quantitative wound assessment showed minor differences between the three color types (Fig. 5). PMNL and MM scored marginally higher in the Silverblue mink than in Brown and Blue Iris, and endothelial cell activity had a slightly lower score in Blue Iris than the other color types.

Livers showed mild generalized vacuolation of hepatocytes in all mink. Furthermore, all mink showed mild to marked splenic congestion together with proliferation of periarteriolar lymphoid sheaths/lymphatic nodules and increased numbers of megakaryocyte. Regional lymph nodes were characterized by active lymphatic nodules. Some lymph nodes, however, showed a general thinning of the lymphocyte population in all (6 lymph nodes) or

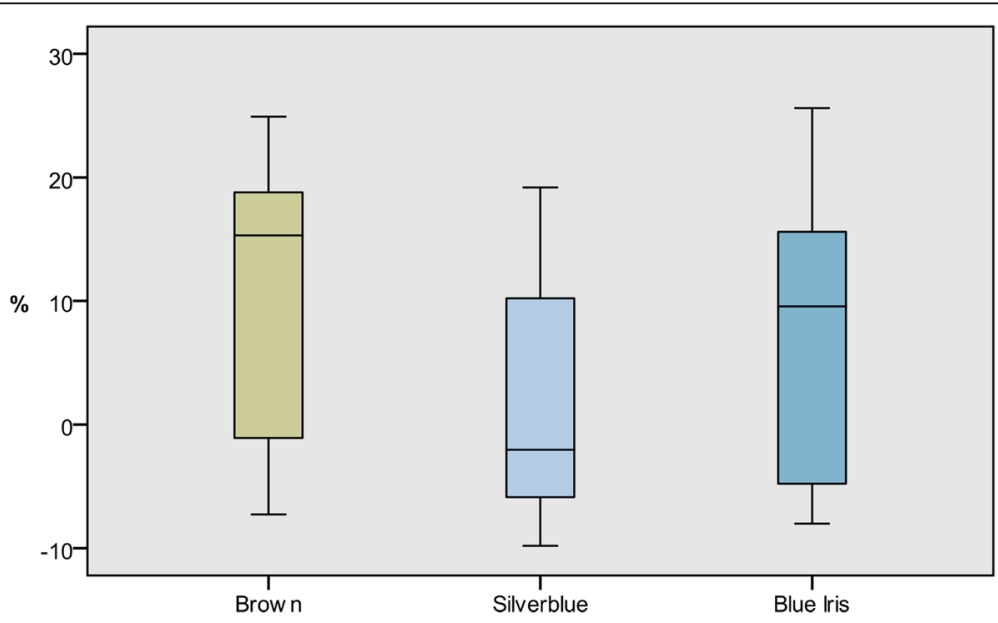

Fig. 3 Percentage wound size reduction from day 0 to day 2 for the color types Brown, Silverblue and Blue Iris 


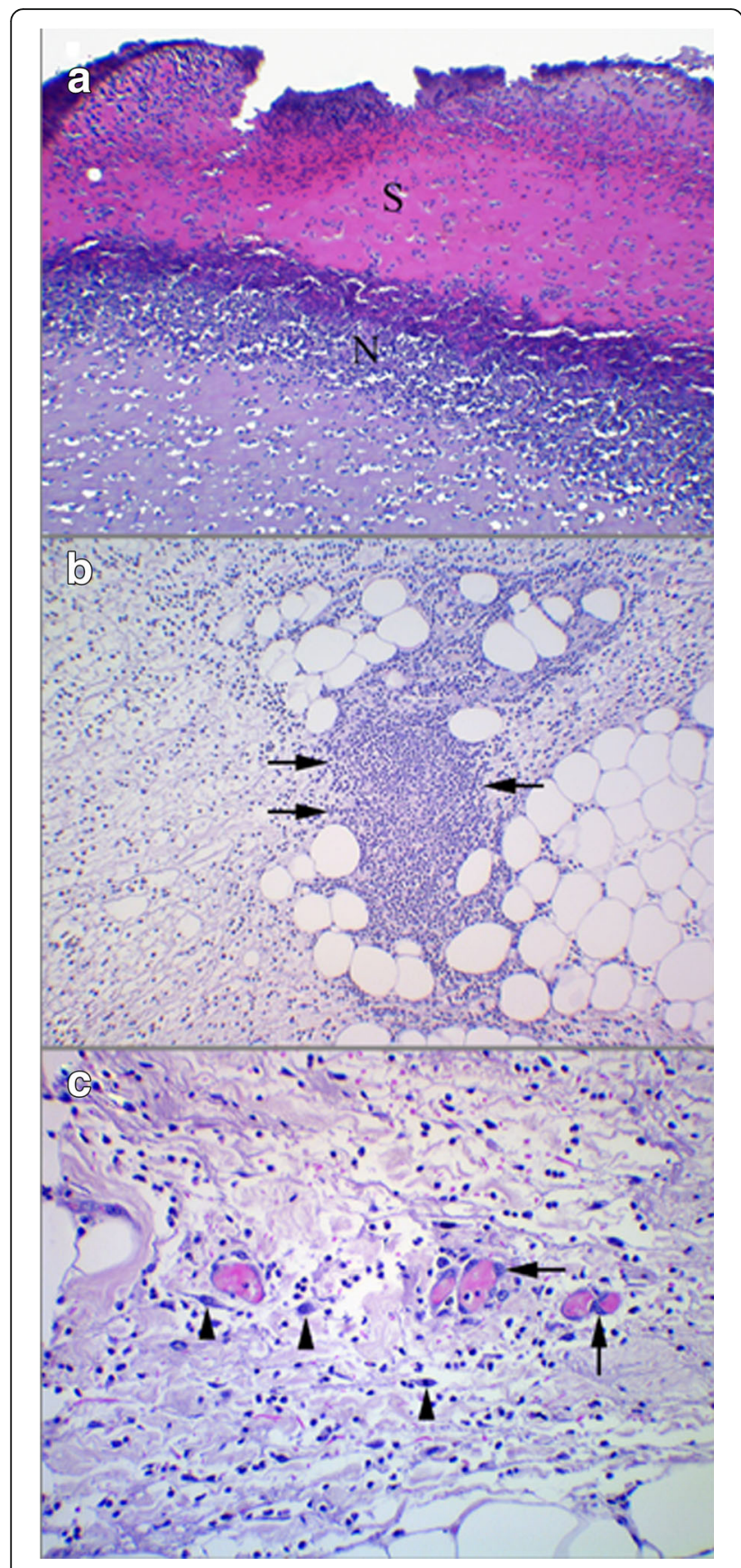

Fig. 4 Wounds day 2. a: Blue Iris mink. A scab of non-vital tissue (S) demarcated by a zone of neutrophils (N). HE. $\times 100$. b: Silverblue

mink. Micro-abscess (arrows) located in edematous subcutis beneath the wound surface. HE. $\times 100$. c: Silverblue mink. Blood filled vessels showing plumping of endothelial cells (arrows). Fibroblasts (arrow heads) in various stages of activation can be seen. HE. $\times 200$

certain parts (8 lymph nodes) of the cut surface. Varying degrees of erythrophagocytosis was seen in 15 regional lymph nodes. In all animals, adrenal glands were approximately $50-100 \%$ larger than adrenal glands from healthy adult mink without wounds. Control samples of skin and mesenterial lymph nodes showed the normal architecture of each tissue type and were without pathological changes.

\section{Blood parameters}

The concentration of SAA increased significantly postwounding (paired-samples t-test; $t=-4.748 ; \mathrm{df}=17$; $P<0.0001$ ). The mean basal level was $6.1 \mu \mathrm{g} / \mathrm{ml}$ (range $5.0-12.7 \mu \mathrm{g} / \mathrm{ml}$ ) and increased to $1357.1 \mu \mathrm{g} / \mathrm{ml}$ (222 fold increase) on day 2 . There was no significant differences between the three color types when comparing pre and postwounding concentration difference in ANOVA $(\mathrm{F}=0.739$; $\mathrm{df}=2 ; P=0.494)$.

Total leucocyte, band neutrophil, lymphocyte and thrombocyte numbers were within normal ranges in all cases. The number of circulating segmented neutrophils increased from day 0 to day 2 , but remained within the reference interval in all but six individuals, whose levels rose above the reference interval to between 10.1 to $13.0 \times 10^{9} / \mathrm{l}$. There was a drop in circulating lymphocyte numbers from day 0 to day 2 , but all values remained within the reference interval. Erythrocyte numbers decreased from day 0 to day 2 . Five mink, all of the color type Blue Iris, had moderate to severe regenerative to non-regenerative anemia on day 2 characterized by a decrease in total erythrocyte numbers, hematocrit and hemoglobin concentration. Moreover, all Blue Iris mink showed vesicle-like inclusion bodies of varying size in a proportion of the circulating neutrophils.

\section{Bacteriology}

Bacteria were cultured from all wounds on day 2. In 9 wounds, the bacterial isolates were from the Staphylococcus intermedius group (SIG) which was found as monoculture in 2 wounds and in mixed culture in 7 wounds. The bacterial isolates are given in Table 3. There was no relationship between color type and wound bacterial species.

\section{Discussion}

The most pronounced effect of color type on wound healing was on the differences in wound size reduction from day 0 to day 2, which showed a greater contractile ability in Brown mink than in Blue Iris and Silverblue mink (Fig. 3). The differences were, however, found not significant and thus represent tendencies. The reason for the differences may be associated with genetic factors modulating the composition of the skin or the body's ability to raise an immunological response and react to tissue damage [33]. Our hypothesis that Aleutian mink would show delayed or inferior wound healing compared to other color types was only partly confirmed, as the Silverblue mink in this study showed slower wound size reduction than the Aleutian Blue Iris mink. This indicates that factors associated with healing in other color 


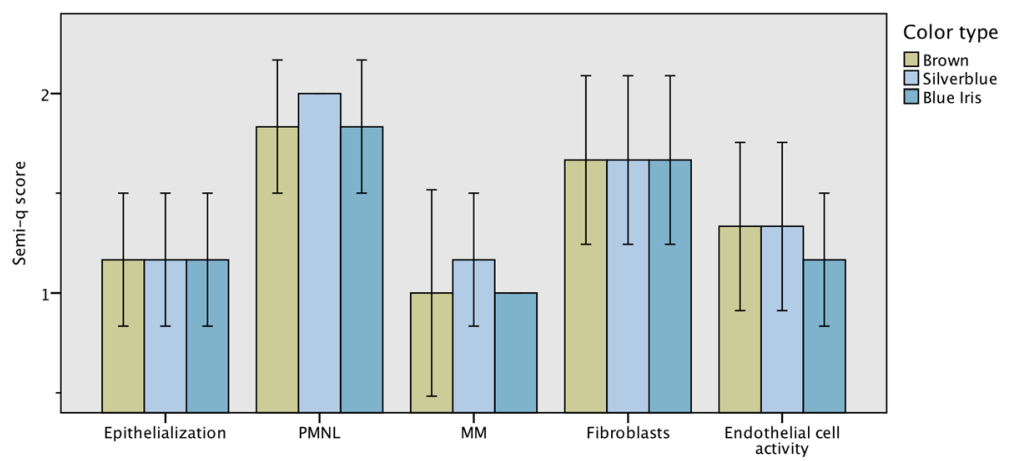

Fig. 5 Histopathological wound examination. Semi-quantitative analysis (y-axis indicates score, see Table 2) of histological changes related to colour type. $\mathrm{PMNL}=$ polymorphonuclear leukocytes; $\mathrm{MM}=$ monocytes/tissue macrophages. $+/-2 \mathrm{SE}$

types may be equally important determinants of wound healing and therefore of importance to the fur industry.

The $48 \mathrm{~h}$ duration of the study was chosen because of the hypothetical presence of both early and late acute stage inflammatory cells [23]. The minor differences in average scores of the semi-quantitative histological analysis indicate that color type does not influence these important histological parameters significantly. It can thus be assumed, that the histological parameters studied can be used as designators of wound age regardless of color type, at least in the early stages of healing. The histopathological appearance of the mink wounds was easily comparable to findings in other mammals, as expected. Our wound model is comparable to studies of wound healing in the dog and cat [12-14]. Mink are closer phylogenetic relatives to dogs than to cats [34], but show high resemblance to the cat karyotype [35]. Looking at early wound healing in these carnivores, there seems to be greater degree of edema formation in the dog than in the cat [14]. Early wound healing in mink seems therefore most comparable to wound healing in the cat, as we saw only slight edema formation on day 2 post-wounding in our study.

The mink showed loss of body weight from day 0 to day 2. Apart from the wounds, the mink were healthy and were in their growth period, so weight loss is considered abnormal. We speculate that the weight loss was the result of reduced feed intake post-wounding; however, it is not certain whether this was due to stress or fatigue from handling, an effect of anesthesia, or the presence of wounds. The enlargement of adrenal glands was apparently caused by hyperplasia and/or hypertrophy of the adrenal zona fasciculata and medulla. Chronic stress can lead to adrenal enlargement [36] and even acute heat stress has been shown to cause a slight increase in adrenal mass in rats [37]. The observed adrenal hyperplasia may indicate that stress was involved, but adrenal changes related to stress has apparently not been studied in the mink. Including negative controls in the form of a handled, non-wounded group as well as a sham-treated group of mink would be warranted in future studies in order to more accurately explain the cause of adrenal enlargement as well as weight loss. Apart from the effect on adrenal morphology, stress is known to influence the wound healing process by causing a delay in tissue repair [38].

Splenomegaly and lymphadenopathy of regional lymph nodes reflect the microscopic findings of splenic congestion and proliferation of white pulp and lymph node activity, which was not a surprising finding given the wounds and resulting inflammatory response. In our experience, the spleen of mink is very reactive in the case of injury; however, splenic congestion and enlargement may furthermore be the result of the barbiturate used for euthanasia of the mink [39]. Again, negative controls would have been beneficial in order to differentiate between the possible mechanisms of splenic enlargement.

Table 3 Bacterial isolates from all day 2 wounds

\begin{tabular}{llll}
\hline Mink number & Brown & Silverblue & Blue Iris \\
\hline 1 & SIG monoculture & SIG + Streptococcus canis & Streptococcus equi monoculture \\
3 & SIG monoculture & SIG + Streptococcus dysgalactiae & Streptococcus canis monoculture \\
4 & Staphylococcus schleiferi monoculture & SIG + Streptococcus sp. & SIG + Pasteurella canis \\
5 & Streptococcus dysgalactiae monoculture & SIG + Corynebacterium ulcerans & SIG + Corynebacterium ulcerans \\
6 & SIG + unidentified sp. & Bacillus cereus + Streptococcus dysgalactiae & Staphylococcus schleiferi + Streptococcus equi \\
\hline
\end{tabular}


An interesting finding was that all five mink exhibiting anemia on day 2 were of the color type Blue Iris. All mink showed a decrease in hematocrit on day 2 compared to day 0 , which may be due to blood sampling. However, adding the blood loss from the prolonged bleeding in Blue Iris mink likely explains why anemia was only observed in this color type. The blood loss was, however, not quantified. The Chédiak-Higashi syndrome is linked to the Aleutian trait of Blue Iris mink, and is known to cause delayed hemostasis and increased tendency for wound infection due to a defective platelet aggregation function and a lower resistance to infection $[18,21,40]$. The finding of inclusion bodies in circulating neutrophils of Blue Iris mink in this study is characteristic of the Chédiak-Higashi syndrome. The inclusion bodies represent enlarged lysosomes showing impaired ability to fuse with phagosomes containing foreign particulates like invading bacteria engulfed by the cell [19-22]. Three mink of the color type Blue Iris showed purulent exudate, strongly indicating wound infection, whereas the same was true for two Brown and two Silverblue mink. However, these numbers are not enough to conclude, that mink carrying the Aleutian trait are more susceptible to wound infection.

The function and expression of SAA and its use as a sensitive marker of inflammation has been studied in many species including the mink [41-46]. In accordance with results from our previous study on early wound healing in mink, we found a significant mean increase of SAA concentration from day 0 to day 2 ( 222 fold). There was, however, no effect of color type on the SAA response.

The isolation of a large proportion of bacteria from the Staphylococcus intermedius group (SIG) from the wounds is in accordance with findings in our previous study of experimental wounds. SIG comprises Staphylococcus intermedius, Staphylococcus pseudintermedius and Staphylococcus delphini group A and B [47], which could not be distinguished by MALDI-TOF MS. However, the isolates are most likely Staphylococcus delphini Group A [48], which has been reported to be an opportunistic pathogen in mink [48-50]. Whether the isolated bacteria were part of an early infectious process or just wound contaminants was not evident, though the presence of microabscesses and cellulitis in some wound specimens may indicate spreading infection. Moreover, a relationship between color type and microbiological findings could not be deduced. The presence of bacteria in the wounds is, however, likely to influence the process of wound healing [24-26].

\section{Conclusions}

To conclude, we have studied the process of early wound healing in a wound model in farmed mink of different colors. The most striking finding was the difference in contractile ability, where Brown showed the greatest wound size reduction followed by Blue Iris and Silverblue. Only minor differences in histopathological parameters were found between the color types. Bacteria, mainly SIG isolates, were cultured from all wounds; however, the significance of the isolates is unknown. Finally, we found a highly significant rise in SAA from day 0 to day 2 indicating a profound effect of wounds on the acute phase response in mink. The results indicate that color type may affect speed of wound healing, which may have implications for clinical/practical wound management. Furthermore, the marked rise in SAA post-wounding suggests that wounds have a significant effect on the mink immune system and that wound healing is a highly prioritized physiological process. Future studies of the effect of color type and other factors on wound healing including late stage healing and breaking strength of healed skin is considered relevant.

\section{Abbreviations}

ANOVA: Analysis of variance; EDTA: Ethylene-diamine-tetra-acetic acid; ELISA: Enzyme-linked immunosorbent assay; HE: Hematoxylin and eosin; MALDI-TOF: Matrix-assisted laser desorption/ionization time of flight; MM: Monocyte/tissue macrophage; PMNL: Polymorphonuclear leukocyte; SAA: Serum amyloid A; SIG: Staphylococcus intermedius group

\section{Acknowledgements}

We would like to thank Betina G. Andersen, Elizabeth W. Petersen and Heidi $\mathrm{G}$. Andersen for their excellent laboratory assistance as well as Dennis Brok, Frederik Andersen, Kristiane Barington, Berit H. Rasmussen and Anne K. Nissen for valuable technical help.

\section{Funding}

This work was co-funded by The Danish Fur Breeders' Association, The Danish Council for Technology and Innovation and Pelsdyrafgiftsfonden (Danish fur animal tax fund). The funding sources had no involvement in the study design, in the collection, analysis and interpretation of data or in the writing and submission of the manuscript for publication.

\section{Availability of data and materials}

The datasets analyzed during the current study are available from the corresponding author on reasonable request.

\section{Authors' contributions}

AJ designed, planned and coordinated the study/experiment, performed the pathological analyses and all data analyses and drafted the manuscript. HEJ and ASH participated in designing the study and in the experimental procedure. JFA participated in the statistical analysis. PMH performed the SAA analysis. BA and PD performed the bacteriological analyses. All authors read and approved the final manuscript.

\section{Competing interests}

The corresponding author (AJ) has previously been affiliated with the Danish Fur Breeders' Association co-funding this work

Consent for publication

Not applicable.

Ethics approval

The protocol was approved by the Danish Animal Experiments Inspectorate (license number 2012-15-2934 - 00261).

\section{Publisher's Note}

Springer Nature remains neutral with regard to jurisdictional claims in published maps and institutional affiliations. 


\section{Author details}

Kopenhagen Fur, Langagervej 60, DK-2600 Glostrup, Denmark. ${ }^{2}$ Department of Veterinary Disease Biology, Faculty of Health and Medical Sciences, University of Copenhagen, Ridebanevej 3, DK-1870 Frederiksberg C, Denmark. ${ }^{3}$ Department of Large Animal Sciences, Faculty of Health and Medical Sciences, University of Copenhagen, Grønnegårdsvej 8, DK-1870 Frederiksberg C, Denmark. ${ }^{4}$ National Veterinary Institute, Technical University of Denmark, Bülowsvej 27, DK-1870 Frederiksberg C, Denmark. ${ }^{5}$ Department of Veterinary Disease Biology, Faculty of Health and Medical Sciences, University of Copenhagen, Ridebanevej 3, DK-1870 Frederiksberg C, Denmark.

Received: 2 November 2015 Accepted: 8 May 2017 Published online: 22 May 2017

\section{References}

1. The Scientific Committee on Animal Health and Animal Welfare. The Welfare of Animals Kept for Fur Production. European Commission, Health \& Consumer Protection Directorate-General. 2001. https://ec.europa.eu/food/ sites/food/files/safety/docs/sci-com_scah_out67_en.pdf. Accessed 19 May 2017.

2. Clausen T. Hvad dør minken af gennem et produktionsår [causes of mink mortality through a production year]. Husdyrbrug Internal report of Danmarks JordbrugsForskning. 2006;2:68-78. Danish

3. Hansen M, Weiss V, Clausen T, Lassen M, Mundbjerg B. Screening of kit mortality on mink farms in Denmark from weaning to pelting. NJF seminar no. 403, Kolding, Denmark; 2007. p. 10.

4. Jespersen A, Agger JF, Clausen T, Bertelsen S, Jensen HE, Hammer AS. Anatomical distribution and gross pathology of wounds in necropsied farmed mink (Neovison vison) from June and October. Acta Vet Scand. 2016;58:6.

5. Efimov EA. Differences in regeneration of skin in different species of mammals. Biull Eksp Biol Med. 1976;81:922-5.

6. Fronczek J, Lulf R, Korkmaz HI, Witte Bl, van de Goot FR, Begieneman MP, et al. Analysis of inflammatory cells and mediators in skin wound biopsies to determine wound age in living subjects in forensic medicine. Forensic Sci Int. 2015;247:7-13.

7. Munro R, Munro HMC. Some challenges in forensic veterinary pathology: a review. J Comp Pathol. 2013;149:57-73.

8. Ansell DM, Holden KA, Hardman MJ. Animal models of wound repair: are they cutting it? Exp Dermatol. 2012;21:581-5.

9. Dorsett-Martin WA. Rat models of skin wound healing: a review. Wound Rep Reg. 2004;12:591-9.

10. Wong WW, Sorkin M, Glotzbach JP, Longaker MT, Gurtner GC. Surgical approaches to create murine models of human wound healing. J Biomed Biotechnol. 2011;2011:969618

11. Lindblad WJ. Considerations for selecting the correct animal model for dermal wound-healing studies. J Biomater Sci Polymer Edn. 2008;19:1087-96.

12. Bohling MW, Henderson RA, Swaim SF, Kincaid SA, Wright JC. Cutaneous wound healing in the cat: a macroscopic comparison with cutaneous wound healing in the dog. Vet Surg. 2004;33:579-87.

13. Bohling MW, Henderson RA, Swaim SF, Kincaid SA, Wright JC. Comparison of the role of the subcutaneous tissue in cutaneous wound healing in the dog and cat. Vet Surg. 2006;35:3-14.

14. Bohling MW, Henderson RA. Differences in cutaneous wound healing between dogs and cats. Vet Clin Small Anim. 2006:36:687-92.

15. Guo S, DiPietro LA. Factors affecting wound healing. Crit Rev Oral Biol M. 2010;89:219-29.

16. Hosoda K, Hammer RE, Richardson JA, Baynash AG, Cheung JC, Giaid A, et al. Targeted and natural (piebald-lethal) mutations of endothelin-B receptor gene produce megacolon associated with spotted coat color in mice. Cell. 1994;79:1267-76.

17. Webb AA, Cullen CL. Coat color and coat color pattern-related neurologic and neuro-ophthalmic diseases. Can Vet J. 2010:51:653-7.

18. Anistoroaei R, Krogh AK, Christensen K. A frameshift mutation in the LYST gene is responsible for the Aleutian color and the associated ChédiakHigashi syndrome in American mink. Anim Genet. 2012:44:178-83.

19. Blume RS, Padgett GA, Wolff SM, Bennett JM. Giant neutrophil granules in the Chediak-Higashi syndrome of man, mink, cattle and mice. Can J Comparat Med. 1969;33:271-4.

20. Kaplan J, De Domenico I, Ward DM. Chediak-Higashi syndrome. Curr Opin Hematol. 2008;15:22-9.
21. Root RK, Rosenthal AS, Balestra DJ. Abnormal bactericidal, metabolic, and lysosomal functions of Chediak-Higashi syndrome leukocytes. J Clin Invest. 1972;51:649-65.

22. White JG, Clawson CC. The Chédiak-Higashi syndrome: the nature of the giant neutrophil granules and their interactions with cytoplasm and foreign particulates. Am J Pathol. 1980;98:151-96.

23. Baum CL, Arpey CJ. Normal cutaneous wound healing: clinical correlation with cellular and molecular events. Dermatol Surg. 2005;31:674-86.

24. Edwards R, Harding KG. Bacteria and wound healing. Curr Opin Infect Dis. 2004;17:91-6.

25. Misic AM, Gardner SE, Grice EA. The wound microbiome: modern approaches to examining the role of microorganisms in impaired chronic wound healing Adv Wound Care (New Rochelle). 2014:3:502-10.

26. Scales BS, Huffnagle GB. The microbiome in wound repair and tissue fibrosis. J Pathol. 2013:229:323-31.

27. Clark RA, Kimball HR. Defective granulocyte chemotaxis in the Chediak-Higashi syndrome. J Clin Invest. 1971:50:2645-52

28. McDonald TL, Weber A, Smith JW. A monoclonal antibody sandwich immunoessay for serum amyloid a (SAA) protein. J Immunol Methods. 1991;144:149-55.

29. Hein J, Spreyer F, Sauter-Louis C, Hartmann K. Reference ranges for laboratory parameters in ferrets. Vet Rec. 2012;171:218-23.

30. Hunter DB. Mink hematology and clinical biochemistry. In: Hunter DB and Lemieux N, editors. Mink. Biology, health and disease, 1st edition. Ontario, Canada: Graphic and Print Services, University of Guelph; 1996. p. 7-1 to 7-5.

31. Hammer AS, Dietz HH. Necropsy of the mink. In: Jensen HE, editor. Necropsy. A handbook and atlas. Frederiksberg, Denmark: Biofolia; 2011. p.231-250.

32. Luna LG. Methods for connective tissue. In: Luna LG, editor. Manual of histologic staining methods of the armed forces Institute of Pathology. 3rd ed. New York: Blakiston Division, McGraw-Hill; 1968. p. 72-99.

33. Dao H, Kazin RA. Gender differences in skin: a review of the literature. Gender Med. 2007:4:308-28.

34. Agnarsson I, Kuntner M, May-Collado LJ. Dogs, cats, and kin: a molecular species-level phylogeny of Carnivora. Mol Phylogenet Evol. 2010;54:726-45.

35. Hameister H, Klett C, Bruch J, Dixkens C, Vogel W, Christensen K. Zoo-FISH analysis: the American mink (Mustela Vison) closely resembles the cat karyotype. Chromosom Res. 1997;5:5-11.

36. Ulrich-Lai YM, Figueiredo HF, Ostrander MM, Choi DC, Engeland WC, Herman JP. Chronic stress induces adrenal hyperplasia and hypertrophy in a subregion-specific manner. Am J Physiol-Endoc M. 2006;291:E965-73.

37. Petrovic-Kosanovic D, Velickovic K, Koko V, Jasnic N, Cvijic G, Miloševic MC. Effect of acute heat stress on rat adrenal cortex - a morphological and ultrastructural study. Cent Eur J Biol. 2012;7:611-9.

38. Gouin J-P, Kiecolt-Glaser JK. The impact of psychological stress on wound healing: methods and mechanisms. Immunol Allergy Clin. 2011;31:81-93.

39. O'Brien RT, Waller KR, Osgood TL. Sonographic features of drug-induced splenic congestion. Vet Radiol Ultrasoun. 2004;45:225-7.

40. Bell TG, Padgett GA, Patterson WR, Meyers KM, Gorham JR. Prolonged bleeding time in Aleutian mink associated with a cyclo-oxygenase-independent aggregation defect and nucleotide deficit in blood platelets. Am J Vet Res. 1980;41:910-4

41. Eklund KK, Niemi K, Kovanen PT. Immune functions of serum Amyloid a. Crit Rev Immunol. 2012;32:335-48.

42. Husby G, Natvig JB, Sletten K, Nordstoga K, Anders RF. An experimental model in mink for studying the relation between amyloid fibril protein $A A$ and the related serum protein SAA. Scand J Immunol. 1975:4:811-6.

43. Marhaug G, Husebekk A, Husby G, Sletten K, Børresen AL, Lium B, et al. Serum Amyloid a protein (SAA) from mink, horse, and man: a comparative study. In: Glenner GG, editor. Amyloidosis. New York: Springer; 1986. p. 139-47.

44. Marhaug G, Husby G, Dowton SB. Mink serum Amyloid a protein. J Biol Chem. 1990;265:10049-54.

45. Marhaug G, Hackett B, Dowton SB. Serum Amyloid a gene expression in rabbit, mink and mouse. Clin Exp Immunol. 1997;107:425-34.

46. Rygg M, Nordstoga $K$, Husby G, Marhaug G. Expression of serum amyloid a genes in mink during induction of inflammation and amyloidosis. Biochim Biophys Acta. 1993:1216:402-8

47. Sasaki T, Kikuchi K, Tanaka Y, Takahashi N, Kamata S, Hiramatsu K. Reclassification of phenotypically identified Staphylococcus intermedius strains. J Clin Microbiol. 2007:45:2770-8. 
48. Guardabassi L, Schmidt KR, Petersen TS, Espinosa-Gongora C, Moodley A, Agersø Y, et al. Mustelidae are natural hosts of Staphylococcus delphini group a. Vet Microbiol. 2012;159:351-3.

49. Chalmers G, McLean J, Hunter DB, Brash M, Slavic D, Pearl DL, et al. Staphylococcus spp., Streptococcus Canis, and Arcanobacterium phocae of healthy Canadian farmed mink and mink with pododermatitis. Can J Vet Res. 2015;79:129-35.

50. Sledge DG, Danieu PK, Bolin CA, Bolin SR, Lim A, Anderson BC, et al. Outbreak of neonatal diarrhea in farmed mink kits (Mustella vison) associated with enterotoxigenic Staphylococcus delphini. Vet Pathol. 2010;47:751-7.

Submit your next manuscript to BioMed Central and we will help you at every step:

- We accept pre-submission inquiries

- Our selector tool helps you to find the most relevant journal

- We provide round the clock customer support

- Convenient online submission

- Thorough peer review

- Inclusion in PubMed and all major indexing services

- Maximum visibility for your research

Submit your manuscript at www.biomedcentral.com/submit
Biomed Central 